\title{
Fluffy metaphors of an overheated debate: Why climate change is neither communicated nor understood as an existential threat? ${ }^{1}$
}

\author{
Bálint Forgács \& Csaba Pléh
}

\begin{abstract}
Metaphors of climate change, as many other scientific metaphors, are often inaccurate, if not in their intended content but in their form and emotional valence. A literal 'greenhouse' is an eloquent construction designed to preserve heat, 'warmth' is an overall positive notion (as opposed to 'overheating'). First, we are going to overview how metaphors are comprehended, from their neural processing to their use in communication in an attempt to describe their working. Next, we are going to explore how metaphors in science deliver messages and how they spread, focusing on two powerful metaphors: an identical replication theory (memetics), and a vision constant reformulation through viral spreading (epidemiology). The form-content distinction is particularly relevant to how scientific metaphors frame debates via their spreading: it is the form that is transmitted, but which are the analogous parts of the content that should be carried over? We then turn to the challenges of climate communication: the reasons for climate metaphors not fulfilling their purpose (e.g., due to the implications of their literal reading); the hostile environment the fossil fuel industry has created for climate scientists (e.g., disinformation and defamation campaigns); the strategies climate scientist could adapt as a community to inform the public and decision makers of the looming cataclysm (e.g., finding a unitary voice as a group with privileged access to specialized knowledge). Next, we are going to address the dire, literal consequences of climate destruction and present ideas on how metaphors and expressions could be improved to transmit a message appalling enough to prompt action. We conclude by an overview of cognitive limitations of everyday thinking and mechanisms of inferential communication to provide ideas for science communicators in persuading contemporaries. Scientists and science journalists should choose their metaphors particularly carefully regarding climate change, as minor misconceptions are leading mankind towards collective extinction.
\end{abstract}

Keywords: metaphor, metaphors of science, climate, global warming, greenhouse effect

\footnotetext{
${ }^{1}$ This paper will appear in S. Wuppuluri, A. C. Grayling (Eds.), Metaphors and Analogies in Sciences and Humanities: Words and Worlds. Springer - Synthese Library. We would like to thank the insightful suggestions of Ferenc Jordán on a previous version of this paper. This work was funded by an NKFIH Young Researcher grant (125417) to Bálint Forgács.
} 


\section{Introduction}

In contrast to classical antique Greek wisdom, it has been argued for over a century that figures of speech and metaphors are utilized not mainly in poetry and rhetoric (Aristotle, $350 \mathrm{BC} /$ 1968), but they occur frequently in everyday language. Novel metaphorical extensions are a driving force of natural language change (Bréal, 1900; Du Marsais, 1740), while conventionalized metaphors and idiomatic expressions ('broken heart') have been suggested to permeate everyday language, because thought, cognition and the conceptual system, is metaphorical in nature (Lakoff \& Johnson, 1980). Metaphorical mappings between cognitive domains are thought to be a pinnacle of human cognition (Pinker, 2010), perhaps even the feat that makes us human (Mithen, 1996). Metaphors do seem to play a central role in formulating and spreading novel ideas, be they concepts we do not happen to have a word for, or scientific models. Consequently, novel metaphors regularly surface in scientific and public discourse, designed to persuade the scientific community or to communicate complex theories for the wider public in a simplified form. While metaphors could reveal important similarities or analogies (Bowdle \& Gentner, 2005), they could also set a path of thought that eventually lead to a dead end, but they can also be exploited to purposefully distract, cover up inconvenient truths, or derail public discourse. One prime example is the case of climate science.

Besides the ambiguity surrounding the exact meaning of metaphorical expressions in scientific and public discourse about the changing climate (e.g., 'greenhouse'), another source of ambiguity is how literally-figuratively scientific terms should be understood - or even what the exact literal meaning is. For example, what is the meaning of 'warming' in 'global warming'? 'Global warming' might mean cooling, droughts, or sea level rise in various regions, but even if it means warming per se, what is warming? An increase in the average, the maximum, the minimum temperature or all of the above? Finally, it is often not clear what the consequences of a 1,2 or $4^{\circ} \mathrm{C}$ warming are, or if such a difference is meaningful at all, when during the course of a single day most people experience warming a magnitude greater. Further on 'warm' is conceived in general as a positive welcoming qualification in the emotional theory of connotative meanings (Osgood, 1962). Therefore, an analysis of how metaphorical expressions influence, for the better or the worse, our understanding and debates, shall be complemented with the extent of how metaphorical or literal the interpretation of terms and expressions is intended and received. If 'global warming' is understood not as a tiny, symbolic shift but a literal disastrous cause of the collapse of ecosystems sustaining organized human communities or even all human sized mammals, the reality and the existential nature of the threat might be easier to perceive, and the urgency of action might be taken more seriously. 
In the following chapter we are going to lay out the state of the art of the cognitive neuroscience of metaphorical language comprehension: what are the prominent models and recent experimental findings on the neural mechanisms that enable the rapid deciphering of figurative meaning? Then, we are going to turn to how metaphors are used in conversations and communication: what are the pragmatic-inferential mechanisms that we employ when figurative senses are on offer, and such interpretations are reached, and how are metaphors created, spread, and stabilized? Next, we are going to turn towards the use of metaphors in scientific and public discussions of climate change and in what sense they might be misleading: why positively valenced words ('warming' or 'change') or passive language ('catastrophe' or 'breakdown') dodge responsibility and distort the perception of duties and opportunities? Finally, we are going to lay out some ideas for scientists and science journalists to consider when choosing and developing metaphors to express novel ideas: how to adapt to the rapidly transforming on-line, social media landscape in the post-truth age.

\section{How do metaphors work?}

Ever since scholars tried to make sense of what metaphor is, they offered several metaphors for metaphor itself. These explanations, definitions, comparisons or categorizations are meant literally, but remain figurative in the sense that the very act of saying that one thing (metaphor) is like or is in fact something else, is metaphorical thinking. One of the first metaphor for metaphors, put forward by Aristotle (350 BC / 1968), is that METAPHOR IS A TRANSFERENCE 2 , of the meaning of a word to another word. For example, "There lies my ship" whereas it is in fact anchored. Grice (1975) proposed that a METAPHOR IS A SIMILE: a metaphor, in essence is a hidden comparison. When we encounter a metaphorical expression ("Odysseus is a lion"), we notice that it cannot be literally true (unless it is about a lion called Odysseus in the local zoo), and in an instant we convert it into a simile by inserting the word 'like' ("Odysseus is like a lion"), making it literally true and thus interpretable. Such a conception lead to the serial processing account of metaphor, because of the additional conversion step. Initial experiments, however, did not find support for this idea (e.g., Blasko \& Connine, 1993; Ortony et al., 1978).

Another line of thought picked up the transference aspect and suggested that metaphorical statements are, in essence, category statements. Just as the linguistic form of nominal metaphors suggests, METAPHOR IS A CATEGORIZATION. Metaphors can be processed

\footnotetext{
${ }^{2}$ Following notation common in cognitive science, SMALL CAPITALS indicate concepts, 'single quotes' mark words, while double quotes mark quotations (the word 'ship' expresses the concept SHIP).
} 
with no delay and directly, since words can have a dual reference, parallel metaphorical and literal senses (Glucksberg, 2003). In the expression "My lawyer is a shark" the word 'shark' refers to the superordinate category of PREDATORY CREATURES, under which LAWYER is rendered. The Career of Metaphor theory (Bowdle \& Gentner, 2005) attempted to integrate the comparison and categorization accounts, when it surfaced that novel, unconventional, metaphors do take longer to process than literal language. As long as a metaphorical expression is unfamiliar, it is processed similarly to a simile, as a comparison, while an analogical structural mapping is established. After repeated encounters, a direct reference to a superordinate category becomes accessible, giving way to rapid, direct categorization. However, accurately matched novel literal expressions take just as long as novel metaphorical ones to process, which throws doubt on the serial, comparison-based processing even of novel metaphors (Forgács et al., 2014). Metaphorical meaning seems to be understood just as rapidly as literal language, even though there does seem to be something out of the ordinary to it. The precise mechanisms of metaphor comprehension have been investigated using cognitive neuroscientific tools as well.

\subsection{Metaphors in the brain}

The first sources on the neural mechanisms of figurative language processing were studies with right hemisphere damaged patients, where a selective impairment of metaphor comprehension was reported despite overall preserved language abilities (Winner \& Gardner, 1977). The finding was remarkable, because the received knowledge at the time was that it is the left hemisphere of the brain which is responsible for language processing. Since then the neuroimaging revolution has demonstrated that language activates both hemispheres, even if the left a bit more, and that the right hemisphere might play a special role in a number of 'soft', pragmatic language functions (Pléh, 2000; Van Lancker Sidtis, 2006). However, the right hemisphere theory of metaphor has not received unequivocal support in healthy individuals, Meta-analyses found that conventional metaphors activate the left hemisphere (Bohrn et al., 2012; Rapp et al., 2012; Yang, 2014), and not even novel metaphors activate the right hemisphere in well controlled paradigms (Forgács et al., 2012, 2014). Such prior reports could have been due to uncontrolled variables (e.g., emotional factors, imaginability, context, etc.) or the pragmatic demands of the experimental situation or material, especially in brain damaged patients who are in trouble with complex social contexts. In sum, metaphor processing neither seems to involve a specialized, right hemisphere system, nor was it possible to reduce it to some sort of social-pragmatic procedure beyond the language competence of the left hemisphere. 
Another influential idea concerning the neural processing metaphor comes from embodied cognition (e.g., Lakoff \& Johnson, 1999). Embodiment argues that cognition is based on bodily experience, and language is processed by sensorimotor brain areas (Gallese \& Lakoff, 2005). Metaphors supposed to play a crucial role in cognition, because they enable abstract thought by establishing mappings between concrete, experiential conceptual source domains (perception and action) and abstract target domains (non-physical ideas), thereby providing structure and content to them. Recent behavioral (Forgács \& Pléh, 2019) and electroencephalography (EEG) experiments did not find evidence in support of this idea, however. Instead of evoking the so-called electrophysiological concreteness effect - a neural response following concrete words, like 'red' or 'table', as opposed to abstract words, like ‘justice' or 'beauty' -, metaphors elicited an abstractness effect (Forgács, 2020; Forgács et al., 2015). The more abstract a metaphorical expression was, the greater neural activity it evoked, which suggests that the activation of concrete, physical, bodily experience does not define figurative language. It should be noted that literal language does activate sensorimotor brain areas (Binder \& Desai, 2011; Pulvermüller, 2005), and quite a number of neuroimaging studies have reported such neural activations to metaphors (e.g., Citron \& Goldberg, 2014; Lacey et al., 2012; Pomp et al., 2018). However, the latter findings could be due to the low temporal resolution of fMRI and likely reflect activation at an early stage of lexical access, after which literal (concrete) senses are suppressed. The results that sensorimotor feature processing does not play a measurable role once metaphorical meaning is retrieved casts doubt on embodiment as a model for cognition at large (as metaphors do not seem to transmit bodily experiences to abstract domains of cognition).

One metaphor comprehension model that predicted the above finding is Abstract Conceptual Substitution theory (Forgács, 2020, 2021; Forgács et al., 2015). The idea is that metaphors are processed similar to polysemy (Murphy, 1997), but as a special case, where specifically the concrete, sensorimotor features are suppressed while abstract properties are enhanced, from which the contextually most relevant one is substituted. For example, the expression "My lawyer is a shark" is understood by ridding the word 'shark' all of its concrete features and one of its abstract properties (aggressive, vicious, or tenacious) one is selected, depending on the context. Figurative meaning is an abstract property, but it is not abstract because it is derived from an abstract superordinate category, of PREDATORY CREATURES, for example (Glucksberg, 2003). It might involve a comparison or a hidden analogy in as much as a LAWYER can be related to a SHARK, but it is neither necessarily based on a complete analogical structural alignment, nor on a direct literal similarity (Bowdle \& Gentner, 2005). Instead of 
defining metaphoricity based on or in contrast to literal meaning, an often elusive notion, the proposal is that concrete, perceptual, sensual language is the baseline relative to which metaphors are figurative - and abstract.

Future studies are necessary to further specify the exact neural mechanisms that allow for metaphorical meaning making and to establish which theory provides a better description of the data. The questions of how metaphors work in context and how contextual relevance of figurative meaning is determined moves away from semantic analysis towards the pragmatics of language use. Pragmatic inferences appear to be crucial for utilizing metaphorical meaning in communicative situations. In other words, besides the issue of how an appropriate figurative meaning is figured out, another key question is why we speak figuratively? The next section addresses the pragmatic functions of metaphorical language.

\subsection{The communicative use of metaphor}

What role does figurative language play in communication? Why do we speak figuratively at all, if everything could be said literally? One possible answer is that there are some areas where literal qualifiers are dominated by or intrinsically intertwined with inherently metaphorical expressions. A critical case is the world of sounds and phonetics. As Fónagy (1963) pointed out, scientific phonetics is full of metaphors such as 'high-low' or 'weak-strong' etc., which we do not even recognize as figurative. Fónagy (2001) interprets this as a consequence of the general emotional-iconic embeddedness of spoken language. Similarly, when talking about human personality our everyday language uses plenty of metaphors, which, in a way, reveals and exemplifies the basic dimensions of emotional meaning. Evaluation, Potency and Activity (EPA) as emotional dimensions of words, as identified across cultures and domains by Osgood (1962), remerge in personality impressions (Kuusinen, 1969).

Another possible reason is that a literal paraphrase of a metaphor simply does not yield an identical content: some subtle information and a communicative-cognitive effect is lost. This subtle information might be stemming from the form itself, as different words have different senses and connotations. Using a particular linguistic form to express a hidden, subtle, covert figurative meaning leaves the task of figuring out what the speaker intended to express to the hearer, which is sometimes used strategically in communication. The dual layer of form and meaning in metaphorical language can be utilized to reveal similarities, label phenomena we have no words for, or it can be exploited to cover up some inconvenient truth.

One of the most influential theories of human communication that it is inferential in nature (Grice, 1975; Sperber \& Wilson, 1986). We establish meaning by assuming that speakers 
intend to communicate information and thereby to change our thoughts. Understanding language is not merely decoding messages (Broadbent, 1958) but taking them as evidence for inferring what speakers intend to make us believe. What is said, or the explicature, that is, the linguistic form, can be quite different from what is intended to be conveyed, that is, the implicature. Just think of indirect requests, such as "Could you open the window?", which we typically interpret as requests not as inquiries. Sperber and Wilson (1986) propose that this inferential procedure is governed by relevance: hearers try to reach the greatest informational effect with the least inferential effort. Speaker attribute thoughts to hearers, thoughts that that they aim to change by the hearer's own inferential mechanisms. Therefore, there is a delicate balance of mutually attributed background knowledge, memories of common history, current perception, etc. (the cognitive environment), communicative intentions, and effect-effort calculus to reach the contextually most relevant, intended meaning. Figurative meaning is no exception.

In their deflationary account, Sperber and Wilson (2008) suggest that metaphorical language is not special in any way. It merely falls on the loose end of language use, where inferential mechanisms are not strongly constrained. There is a continuum for narrowing and broadening lexical meaning, which is a means of adjusting word meaning to local content. Word meaning by and large is underdetermined: each word can refer to a myriad of different things in various contexts (Sperber \& Wilson, 1998). When we use words narrowly, they correspond closely to their encyclopedic (or lexical) meaning (e.g., a 'lake house' is a building located near a body of water used, perhaps, for recreational purposes). However, when we use words in a broad sense, or loosely, we leave the inference of what was meant to the hearer, which could be a strategy of making an understatement purposefully (e.g., 'lake house' could refer to a storage near a pond or a luxury castle on a cliff). Loose language use, that is, constructing meaning by broadening, includes all kind of meaning extensions, such as metonymy ('the greens want regulation'), hyperbole ('the city is melting'), approximation ('it's freezing outside'), and even metaphor ('hot topics') (Wilson \& Sperber, 2002). An intriguing phenomenon with metaphor, which makes it somewhat unique despite the deflationary claims, is that it requires some sort of simultaneous broadening (including the figurative) and narrowing (excluding the literal meaning). Abstract Conceptual Substitution's solution for this tension is that narrowing concerns concrete features and broadening abstract properties; there by it also relieves itself from an encyclopedic and/or literal ground of meaning.

The crucial aspect of meaning broadening and loose language use that it can be employed strategically to create ambiguity, which can serve important communicational 
purposes. Indirect speech is a prime example of this use (Pinker et al., 2008), where socially risky opinions, desires, or proposals can be expressed in a veiled manner, like bribing an officer or proposing a sexual adventure. The indirectness of framing ("Is there another way to solve this?") leaves the burden of inference of what was meant by the speaker to the hearer, which in turn, if the hearer is unsatisfied ("Is that an attempted bribery?"), can plausibly be denied by the speaker (“I haven't said anything like that!"). Such an escape route for backtracking creates a negotiation space for sensitive social bargains and relationship negotiations. Metaphorical language can be exploited in similar ways, because of its dual layer of literal form and figurative meaning: sometimes both interpretations are possible and thus are on offer (a regular source of jokes). Moreover, social bargains can take the form of negotiating what was meant by what was said. "It was a joke" or "I didn't mean it literally" is a well-known backtracking strategy in the private and the public domain alike. In short, speaking metaphorically and thereby loosely offers a convenient way to express inconvenient opinions or to make socially risky offers wrapped up in a figurative form, leaving it up for interpretation (Forgács, 2021).

Besides hiding behind them, another way to use metaphors is to reveal something hidden: a concept we do not have a word for in the public lexicon (Sperber \& Wilson, 1998). Such a lack of expressions for novel ideas, refined notions or miniscule personal experiences occurs regularly in everyday life and it is perhaps even more frequent in science, where verbal creativity needs to bridge the mental and public lexicon, to put discoveries into words. Metaphor does not necessarily reveal a similarity per se, it can establish it just as well. For example, the expression 'quark flavors' does not mean that quarks share some structural complexity with real tastes (a similarity), but that there are qualitative differences between them that we may conceptualize as differences between tastes. The point here is that sometimes we use metaphorization to extend the meaning of an existing words to point to an idea we have no word for yet (Forgács, 2021), which is lends metaphors a central role in scientific language.

\section{Metaphors in science}

The inferential and constructive nature of establishing metaphorical meaning leaves a bit of ambiguity even with metaphors created with the intention to reveal and clarify hidden truths. The range of possible interpretations, the level of figurativeness, negotiation of exact meaning are all informed by scientific inquiry, but metaphors can subtly, unintendedly and unnoticedly, drive research over long periods of time. Many authors believe that knowledge is rooted in metaphorical and analogical thinking, and therefore it plays an inevitable role in science (Leary, 1990). In some sense a scientific metaphor is a model in itself: they can be and are transformed 
into testable predictions (Gigerenzer \& Murray, 1987). Powerful, vivid metaphors can also become intellectual obstacles, as they narrow the scope of understanding or the way received knowledge is challenged, and sometimes they can establish broad and pervasive misconceptions. For example, AN ATOM IS A SOLAR SYSTEM model of particle physics at the dawn of quantum mechanics was highly influential but eventually it was dropped, because however vivid an image it evoked, it just did not describe subatomic relations accurately. Sometimes literal and metaphorical terminology go back and for the between disciplines. The information theory of Shannon (1948) applied the literal vocabulary of human communication to a mathematical description of technical systems (the terms like noise, source etc. shows this). Later, however, linguists like Jakobson (1960) and eventually cognitive science as a whole reapplied this technical theory and terminology as a metaphor for human affairs when it described cognition as information processing. Or computers were conceived as models of the mind, but later serves as metaphors for the mind. In some cases, the above two functions of metaphor are mixed: scientific metaphors that were originally intended to bring clarity to a subject matter are exploited to sustain a scientific status quo, which serves carrier, financial or political goals - as it seems to have happened in climate science as well.

\subsection{Metaphors frame the debate}

How exactly can metaphors that were intended to be elucidating become misleading? The culprit is the figurative part, or the vehicle of the metaphor, and more specifically, its literal interpretation. It is not necessarily problematic that the association and connotations of the literal sense of a metaphorically intended expression gains prominence in communication. In everyday conversations, especially when stakes are high, metaphorical expressions open a way to refer to events, experiences, and emotions in a safe and veiled manner (Cameron, 2007): talking about an emotional journey by detailing aspects of physical journeys is one example. Such an extension of the literal layer of scientific metaphors can become misleading, however. The previously filtered literal meaning, the concrete, physical features of the source concept, or even some irrelevant abstract properties of the figurative term could be reactivated even on purpose. Analogies might be worked out in detail during eventual systematic elaboration or scientific debates (as they do not seem to be necessary to coin a novel metaphorical expression in the first place). In the case of the solar system model of atoms, electrons are conceptualized as planets, but in this case the analogy breaks down when the position of electrons is to be scrutinized, however appealing a parallel between planetary and subatomic worlds is. 
The more problematic cases are when a misleading analogy does not break down and keeps framing the discourse. For example, participants preferred rather different policies to tackle crime if it is framed as a MONSTER as opposed to a DISEASE (Thibodeau \& Boroditsky, 2015). Specifically, enforcement was preferred over reform for the MONSTER and the reverse pattern was observed for the DISEASE metaphor. Even though both metaphors have their merits and capture some aspects of reality correctly - there are crimes so hideous that their monstrosity is not a question and criminality can brew and spread -, enforcement is often a treatment of symptoms while medical intervention is targeting the root causes of a social problem. Therefore, in some respect, policy choice is not about the nature of criminality, but a reaction to the framework of the debate, and more specifically, the literal interpretation of the metaphors on offer to describe the world. There is a broader question lurking here from the history of science: what should matter more, the imagistic vision, or the mathematical specification?

\subsection{The spreading of metaphors: memetics vs. epidemiology}

Particularly sensitive is the issue of how metaphors that frame debates and worldviews spread. Two highly influential models of cultural information transmission, memetics (Dawkins, 1976) and epidemiology (Sperber, 1985), propose radically different mechanisms for the spreading of form and content. These two theories of cultural transmission are themselves vivid biological metaphors, both in need of further empirical investigations on how literally their respective source domains, GENES and INFECTIOUS VECTORS should be understood (Pléh, 2003).

Dawkins' ingeniously coined term 'meme' originally did not refer to fast spreading internet sensations of visual jokes but to the smallest unit of cultural information that is transmitted between individuals, just like a gene, the smallest unit of heritable biological information. The idea is that cultural evolution works just like biological evolution, on a level over and above the individual but driven by elements below the individual. Bits of information (beliefs, norms, values, methods, etc.), just like single selfish genes, strive to get replicated and spread from individual to individual, with the key copying mechanism being imitation. The more mind a meme spreads to, the more likely it will make it to the next generation of minds, giving rise to large cultural products from religions through politics to world views and shared cultural knowledge. Actual cultural behavior relates to memes as phenotype to genotype (or 'memotype'): a cultural code can be expressed to varying degrees and in multiple ways, but it is faithfully copied, thus form and content by and large are in close correspondence and are transmitted together. The analogy seems to break down with hereditary lineages, however, since cultural traditions seem to provide rather loose mechanisms of transmission (Pléh, 2003). 
Moreover, meme-like horizontal transmission of genes happens only in bacteria and it does not even serve reproductive purposes, although it can increase reproduction rates indirectly.

Sperber (2001) loudly rejects the idea that imitation could account for the transmission of cultural knowledge (i.e. "public productions"). First of all, not all cultural transmission can be reduced to imitation, but second, more importantly, imitation is not a process of faithful, veridical copying. Sperber's (1996) epidemiology account proposes that it is the main idea, or the content, as understood by the receiver, which is transmitted, not the form. Sperber readily acknowledges that bacteria or viruses de create precise copies in biological epidemics, whereas in cultural epidemics the transmitted copy is not identical to the original one. When we form a mental representation from, and later into, a public representation there are slight modifications that gravitate towards cultural attractors - psychological dispositions that channel or constrain inferences about how to reconstruct and recreate the content. Therefore, much like in sentence processing, the form is lost rather quickly, and what remains is the content, as understood in the first place, in the local, communicative and the broader, cultural context. It should be noted that humans are able to imitate actions in a faithful manner, that is, copy also the means leading to a goal, as opposed to goal focused emulation in apes (Horner \& Whiten, 2005). The ability to learn arbitrary actions and content as culturally relevant, normative information seems to be a human specific adaptation as laid out in the theory of Natural Pedagogy (Csibra \& Gergely, 2009, 2011; Gergely et al., 2002). However, this process seems to be specific to particular developmental and educational contexts, not to the public and open market of ideas.

What is the bearing of cultural transmission on the spreading of scientific terms and metaphors? However appealing the selectionist model of memetics is, the expression is being used in popular culture to fast spreading internet sensations not by chance. 'Meme' has become the restricted entity that it perhaps best describes: visual jokes that are circulated in an identical format - but even them, if become popular, 'go viral'. The infection model appears to have greater explanatory power (Pléh, 2003) by suggesting a spreading of ideas that circulate around existing cultural or cognitive attractors.

When novel ideas, notions, concepts are expressed using an already existing word in an unusual figurative sense, however, it is the word form that gains particular importance: after all that is the new, attention grabbing information. Consequently, even though it will be the form of a novel metaphorical expression that is spreading, it will be its content, the actual meaning that will be bent to accommodate (e.g., the expression 'greenhouse' gases may be the catch, but it could mean different things in different contexts). If the initial inference of metaphorical meaning remains ambiguous because it is unfamiliar, that is, it is not clear which abstract 
property should be selected, a multitude of parallel meanings could remain active, which are going to be pulled by a diverse set of possible cultural attractors during transmission. Further abstract properties could also be generated based on the literal meaning of the original source vehicle term or even concrete features could be brought back in if interpretation is difficult. Such guesses might bring somewhat converging but not identical, parallel interpretations that could remain unnoticed for some time. Even when new information is provided, in the form of additional explanations, parallel interpretations could be updated in parallel, which might eventually lead to parallel universes of comprehension. Taken together, a scientific metaphor might gravitate towards various attractors of cultural time and space throughout its spreading, sometimes shift towards irrelevant abstract senses, or even regress to a more literal meaning. This process might be especially true when a true content is hard to grasp or remember, while the from is a well-spreading catchphrase. Despite its well-known key concepts, climate science has become rather controversial and obscure in many respects partly because the ambiguity around its metaphors.

\section{Metaphors of climate science}

Most metaphors of climate science in circulation in the public domain have apparently failed their main purpose: to provide a clear picture of the severity of the existential threat human kind faces and to trigger immediate action. Why is the language so soft, and why are metaphors not persuasive enough for the broader public and the political-economic decision makers, when the collapse of eco-systems, a mass extinction, and the end of organized human civilization are at stake? There are two particularly notable reasons: 1) fossil fuel interests, companies and countries, have engaged in one of the greatest disinformation PR campaign in history; 2) the reputation management of climate scientists often prompts them to sound modest and reasonable, and to systematically underestimate dire state of our planet. Fueled by the neoliberal political infrastructure that favors short-term profit maximization above common good, which has legalized corporate pressure on political, social, and societal decision, these fossil interest groups encountered almost no resistance in the destruction of the life support system of Earth and of the living habitat of the human race for the next quarterly figures to look good. The next section is going to show what kind of language was born out of the polite, tamed, and modest attitudes behind which climate scientist retreated; the deception strategies the fossil fuel industry employed, including the denial of facts, politicizing science by narrowing contexts and constraining factual background; and destroying researchers and buying off politicians. Then 
strategies the scientific community could utilize to deliver a clear warning to the general public about the consequences of climate destruction are going to be discussed, followed by what 'climate change' literally means, and how metaphors could be improved to better describe it.

\subsection{Climate expressions that create a false impression}

There is quite a number of rather well-known buzzwords, most of them metaphorical, at least to some extent, that are systematically used to describe climate change. In recent years there have been attempts to modify some of these expressions, for example, progressive journalistic reporting started to use 'climate catastrophe' or 'climate breakdown'. However, even these phrases use a passive voice with rather problematic connotations, such as implying blind natural forces, no human responsibility, or no chance to reverse the process. There is some empirical evidence that some climate metaphors work better than others (Russill, 2011; Volmert, 2014), from educational contexts as well (Armstrong et al., 2019; Deignan et al., 2019), yet the real danger at this point is not that a next generation but the current ones do not understand the enormity of the problem. Opinion change is notoriously difficult in adults, especially for those with high social status or in leadership positions. Success is often taken as justification of beliefs and lends an illusion of expertise - one telling example is the "Nobel disease". Instead of providing a comprehensive collection and analysis of metaphors in climate communications, we are going address the most concerning issues of the current terminology via the evaluation of some of the more popular expressions.

\subsubsection{Climate change vs. global warming}

The term 'climate change' and 'global warming' both have been in use from the 1970s onwards, but the former gained prominence over the latter (Figure 1), not only because changes include more than warming but also because climate denialists. Such a label preference became US government policy because it sounds less frightening and less specific (Burkeman, 2003). Neither terms are particularly suitable for public communication of an existential threat, however, since neither have particularly negative connotations. The word 'change' can be positive enough to win elections (Levine et al., 2011), while 'climate change' could mean change in many directions (heating, cooling, etc.). Such a framing has allowed political operatives to question if there is any change at all or to claim that change is a natural phenomenon, and no one should or could resist. However scientifically accurate 'climate change' may be, its vague, passive, and mild tone makes its adaptation by both the UN and 
NASA a rather questionable choice. Even though there is not much figurative in this expression, its meaning is loose enough to allow for a multitude of true and false interpretations.

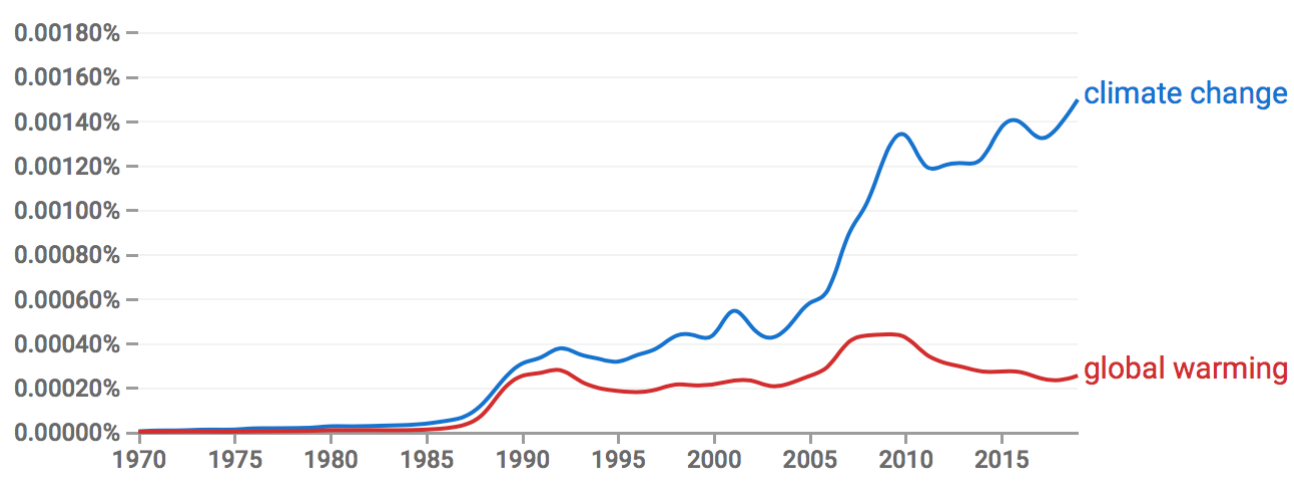

Figure 1. Bigram frequency of the terms 'climate change' and 'global warming' between 1970-2019 in English language books form Google's Ngram Viewer.

'Global warming', the allegedly more frightening term also sounds rather benign: 'warmth' is a positive word (Osgood, 1962), and 'warming' does not typically imply any harm. Moreover, in the context of weather, 'warm' often refers to pleasant and rejuvenating periods (spring or the morning). Such concerns are exacerbated by the rate of global warming, typically discussed in the $1.5-4^{\circ} \mathrm{C}$ range, which might sound absurd for non-experts when a weather report might talk about a warming a magnitude greater, and it is not unusual to adjust the thermostat in one's home within such a small range. Overall, it might be difficult to grasp the threat for the general public and educated non-experts or politicians, especially what the fuss is about keeping global warming below 1.5 or $2^{\circ} \mathrm{C}$. In reality, even a $0.5^{\circ} \mathrm{C}$ difference is likely to have dire costs not only economically and politically, but crucially, in lives (potentially in the millions). Again, 'warming' is not necessarily figurative, but most of its uses are not threatening and overall pleasant (e.g., as opposed to 'overheating').

\subsubsection{Greenhouse effect and the $\mathrm{CO}_{2}$ blanket}

One of the most broadly used metaphors of climate science is the 'greenhouse' effect, which denotes that Earth's atmosphere traps heat as a greenhouse due to accumulating $\mathrm{CO}_{2}$, which leads to dangerous warming. This metaphor is also rather problematic for a number of reasons. Real greenhouses are elegant, delicate structures, making the concept rather appealing. It fuels the misconception that $\mathrm{CO}_{2}$ can be removed instantaneously, just like window panes, also that thereby the heating effect could dissipate rapidly, which might contribute to the "wait-and-see" attitude towards climate destruction (Chen, 2012). An additional highly problematic aspect is 
that real 'greenhouses' are specifically designed to trap heat and fight cold, which could make the false impression that heating is a goal and 'greenhouse effect' means tempering. Moreover, the atmosphere does provide an important moderating greenhouse effect, but this is beside the point of the current global warming. This metaphor is sometimes further explained by another one: $\mathrm{CO}_{2}$ in Earth's atmosphere is a cushy blanket that traps heat under. This image is quite misleading as well: $\mathrm{CO}_{2}$ is not a blanket that can be removed, and one would need to imagine a blanket that constantly thickens - and does so for another 30 years after emissions are cut to zero. Possessing a warm blanket is usually good and useful, unlike wearing gloves on the Bahamas, thus it might not be easy to realize the lethal consequences of such a tender, fluffy blanket. A bathtub metaphor has also been of offer (Armstrong et al., 2019) but its pleasantness and the ease of pulling a plug makes this one quite problematic as well. The actual, negative implications of these metaphors, including 'greenhouse', needs so much clarification that they could be considered to be dropped all together.

\subsection{The responsibility of climate scientists}

For a long period of time, climate scientists fought an uphill battle against the financial interests of fossil fuel companies. These corporations, together with state actors, have been funding an entire infrastructure of climate denial: they obstruct science and sway public opinion by buying off politicians and scientist a like with donations of entire fortunes. These interest groups also mobilized an enormous wealth to discredit scientist (e.g., in PR campaigns), to create ambiguity around findings among non-experts (e.g., by producing "alternative facts"), and to derail public debates (e.g., whether human activity is responsible for the metamorphosis of the atmosphere). Most CEOs focusing on quarterly returns or politicians on election cycles may have no clue about the time scales of biological processes. Such corporate and political tactics and mentality put climate scientists in a delicate situation and prompted coping strategies that limited the scope and force of clearly articulating the deadly consequences of an unnaturally rapid transformation of global climate.

\subsubsection{Corporate war on science}

By no means was the path taken by fossil fuel companies a naïve, sometimes dirty but mostly legitimate campaign along financial interests: they were at forefront of ordering and carrying out scientific studies into their own impact on the climate. For example, an internal report by Exxon in 1982 predicted frighteningly accurately the amount of excess $\mathrm{CO}_{2}$ in the atmosphere and the consequential global temperature increase up to the present day, while Shell's 1988 
internal report vividly depicted the devastating yet irreversible consequences of a climactic collapse (Franta, 2018) ${ }^{3}$. Exxon knew about the threat already since 1977 (Hall, 2015), yet it did not only consciously lied about it (Supran \& Oreskes, 2020) and funded groups working on polarizing opinion by spreading disinformation (Farrell, 2016), but it also joined forces with other fossil fuel companies to actively lobby and buy off government officials in the US ${ }^{4}$. Exxon is of course only one of hundreds of such corporations. Several of these companies employed entire teams of climate scientists to frame themselves as leaders of climate research and greenwash themselves, on the one hand, yet strategically suppressed, shelved or denied even their own research, on the other. More recently, they have shifted strategies and moved towards fostering hopelessness (“doomism”) while advocating for untested, inexistent, or unknown technologies to magically offset and prove a smoke screen for sustained emissions.

Such deceptive strategies from one of the most wealthy and powerful industries in the world have created a hostile environment for climate scientist and likely contributed to the dramatic erosion of confidence in the reliability and trustworthiness of experts and science in general. The charade of directed and manipulated science is well known in the history of science. Some scientists did an honest and conscientious job for oil and coal companies, and sometimes wrong assumptions or even malign intentions advance scientific process. For example, one of the most eminent statisticians of the $20^{\text {th }}$ century, Ronald A. Fisher, simply did not believe that smoking leads to cancer and consequently he vehemently criticized the statistics behind such claims (Fisher, 1958), which, nevertheless, eventually proved correct. That it took about another 40 years for governments to regulate big tobacco is a different story. Another eminent number cruncher, the psychologist Hans J. Eysenck (2000) engaged in sophisticated scientific distraction when he analyzed the relationship of smoking and personality traits. And there is the dark history of hired science: it is not by chance that the very same researchers and journalists contributed to the PR stunts of the tobacco and the fossil fuel industries (Hulac, 2016). This shadowy legacy cannot be dealt with but by the community itself, internally.

\subsubsection{Experts of privileged access to the actual state of Earth's climate}

Since the 'scientific community' is an ideal, not an actual community, it is often not difficult to masquerade as a maverick scientist to deny facts of climate destruction. However, is there any

\footnotetext{
${ }^{3}$ Because the issue of climate communication stretches into the public domain and where investigative journalism plays a critical role, we rely on public media outlets occasionally.

${ }^{4}$ A comprehensive track record of the lobbying efforts of fossil fuel companies at the US Capitol can be found at https://influencemap.org/report/Climate-Lobbying-by-the-Fossil-Fuel-Sector.
} 
reasonable argument for not taking action as long as either 60 or $99 \%$ of scientists agree that humans are in the process of inducing an irreversible transformation of Earth's climate, which will lead to the collapse of organized human civilization if not reversed? The false arguments against taking action were of course fabricated by fossil fuel interests, but the scientific community as a whole, or at least its majority, could stand up firmly against misrepresented or manipulated science, it could ostracize fake scientists and denounce those who distort facts to create mistrust and disbelief, and it could speak clearly from a position of caution to save the biological life-support systems of the planet - instead of taking a worried yet wait-and-see approach itself. Although such a stance has been framed as politically-economically motivated and manipulative ("the green lobby"), but this accusation should not hold the community back from speaking truth to power in a unitary voice.

In such a hostile environment, where entire careers can be derailed by powerful interest ${ }^{5}$, it is well understandable that many scientists took a relatively low profile and engaged in, knowingly or not, swift reputation management. In order to sound credible and reliable, to keep a façade of engaging in debate instead of dismissing fabricated arguments or selective data interpretations, a rather modest tone has been adapted by an effectively self-pacified community. Crucially, climate scientists have been systematically underreporting the potential consequences of the anthropogenic destruction of the climate and the biosphere (Brysse et al., 2013). Adhering to the scientific norms of skepticism, restraint, and moderation in combination with underreporting could have contributed to political and economic decision makers being under the illusion that climate change is distant, controllable, possible to adapt to, and does not pose a life-threatening danger. The blame of "alarmism" is in use as a suppressive strategy, but those who are aware of the magnitude of the threat should have no moral scruples for ringing the alarm, whether they err on the side of caution or not.

Many scientists believe perhaps that his or her role is to present the facts objectively, and dissemination, explanation and prediction is the task of journalists. With no specialized expertise it might be extremely challenging to weigh information appropriately and almost impossible to warn the public credibly as a second hand source. A cautious statement might be scientifically accurate but might downplay and thereby cover up potentially hazardous outcomes - which are of real public interest, even if hypothetical in the present. Reality is not somewhere halfway between denial or acknowledgement of an existential threat, however. We are going to address the issue of scientific communication later on, but public communication

\footnotetext{
${ }^{5}$ For example, the so-called 'climategate': https://www.theguardian.com/environment/2021/feb/27/climatologistmichael-e-mann-doomism-climate-crisis-interview
} 
should sometimes include actions as anchors for intended meaning. Just as clear messages, clear actions by the community of climate scientists are crucial as well, including organized expression and harsh dissemination of the precious knowledge they have privileged access to, notwithstanding emphasizing what they mean by organizing movements, protests, strikes or other forms of civil disobedience to provide weight for their message, if necessary.

\subsection{The real face of anthropogenic climate destruction}

What is the plain, literal, non-gilded meaning of the phrase 'climate change' and what is the real face of climactic transformation? Of course, the original and authentic sources for what is happening to the planet's climate and biosphere are climate scientists. Yet, at least partly due to the above mentioned reasons, the corporate war on truth and the reputation management of climate scientists, the vast majority of the global general public has no clue on what is in store for mankind. Although there is a growing number of people who are aware of the threat, only a handful is aware of its existential magnitude.

Most climate models have been projecting hypothetical future scenarios as a linear continuation of past and present trends and thereby predicted slow, gradual changes. For example, a given amount of additional $\mathrm{CO}_{2}$ shall lead to a proportional amount of heating and sea level rise. Complex natural systems, however, do not typically behave like that on the long run: changes might be exponential and/or non-linear (i.e. sudden and drastic), with a number of qualitatively different alternative outcome states. First of all, modifying one variable could trigger positive feedback loops. For example, increasing the amount of $\mathrm{CO}_{2}$ in the atmosphere leads to heating, which leads to an increased melting of polar ice, and because less ice reflects back less energy from the Sun, heating is further increased. Note that such a feedback is independent of the amount of $\mathrm{CO}_{2}$, which serves merely as an initial trigger. Heat itself can serve as a further trigger, for example for the release of methane, which is a vastly more potent greenhouse gas than $\mathrm{CO}_{2}$ and its emission increases naturally with higher temperatures (YvonDurocher et al., 2014). In such a complex system as the biosphere domino effects and feedback loops create a highly complex structural interdependence across various scales and levels (Rocha et al., 2018). Subtle changes can escalate exponentially and irreversibly.

When a subsystem reaches a point of no return, or a so called tipping point, reversing processes that triggered the flip will not bring back the original state. Intriguingly, the larger ecosystems are, the faster they collapse (Cooper et al., 2020), perhaps partly because they can take more stress than smaller ones, but at their tipping points they burst suddenly. The particularly alarming implications is the robustness and resilience of Earth's biosphere as the 
largest ecosystem might be illusory. Extremely concerning is the possibility that the Amazon rainforest could already have passed its tipping point (De Bolle, 2019). Tipping points for ice sheets, rainforest, permafrost melting, or oceanic currents could trigger each other, in a tipping cascade that could lead to a "Hothouse Earth" (Steffen et al., 2018). Such a chain reaction of local transformation of subsystems necessarily leads to a rapid and irreversible shift in the system as a whole - and it could be triggered even by a single major tipping point. The system is not linear in the sense that tipping points can trigger each other, therefore 'climate change' might be a rapid sudden and irreversible event instead of a gradual shift.

Chaos theory (Gleick, 2011), which is based on non-linear equations, emerged partially from weather science and provided elegant descriptions of a broad range of natural phenomena. It has convincingly shown that complex systems tend to find and sustain equilibrium around mathematical attractors. They are able to tolerate quite considerable changes to one variable or another and maintain their stable state. However, at a non-predictable but well expectable moment, in an instant of deterministic chaos, a minor modification can induce a state change, where the system as a whole moves to another attractor state (Figure 2). This is the reason why systems ecologists are arguing for a kind of natural conservation that tracks and saves the functioning of ecosystems as wholes instead of counting species (e.g., Ortiz \& Jordán, 2021). Saving at least those systems that are possible to do so, because the extinction of a plethora of species is already irreversibly accelerating: extinction breeds extinction (Ceballos et al., 2020).

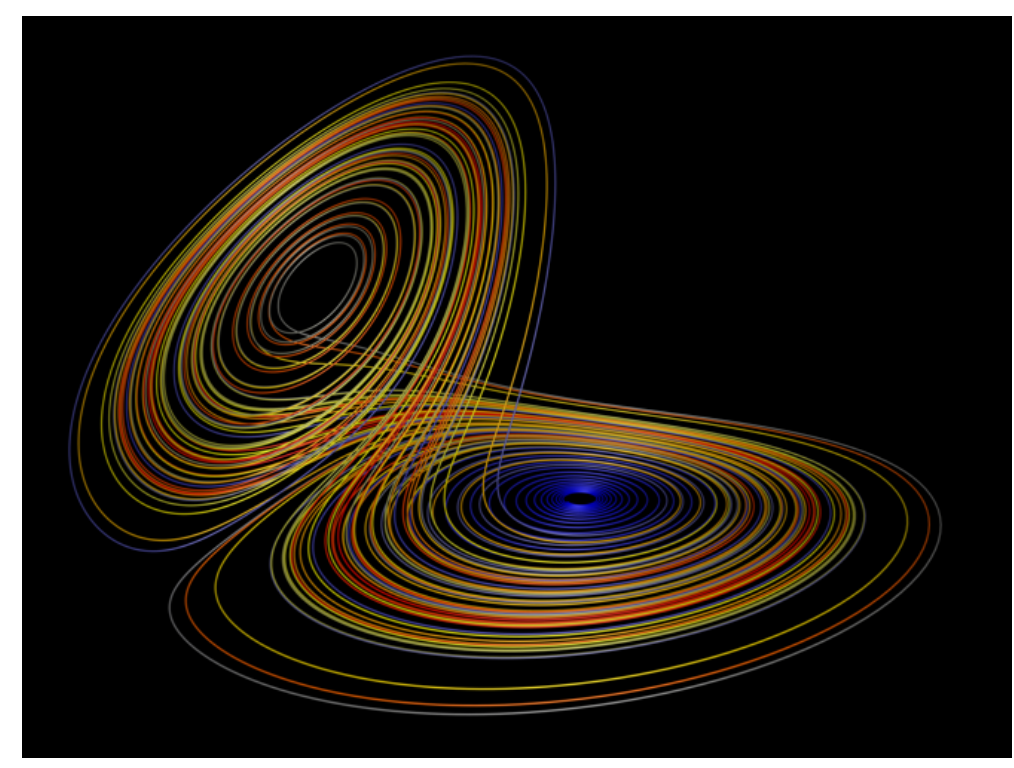

Figure 2. A Lorenz-attractor. Visualization of the solution of a set of non-linear equations circulating around mathematical attractors. Highly complex systems, like Earth's climate might shift from one attractor or relatively stable state (e.g., Ice Age) to another (i.e. hothouse 
state) relatively suddenly before absorbing rather substantial changes. Courtesy of Paul Bourke (http://paulbourke.net/fractals/lorenz/).

Earth's climate system, as a complex, natural, deterministic yet chaotic system with variables perhaps in the tens of thousands, has two main attractor states: the icehouse (glacial or Ice Age) and the hothouse state. The shift between the two might be influenced by the fluctuating position of Earth relative to the Sun - the tilt of its axis, its distance from the Sun, etc., i.e. the Milankovitch cycles - but it is determined by atmospheric processes, since there is no direct correspondence between Earth's position and the four Ice Ages or even the glacialinterglacial shifts. By pumping $\mathrm{CO}_{2}$ in the atmosphere continuously human kind will eventually shift Earth into its hothouse state. If the climate of the planet finds its hothouse equilibrium, it is likely to resist a shift back to the icehouse state just as stubbornly as it has been keeping its balance in the past decades (e.g., oceans swallowing excess $\mathrm{CO}_{2}$ and heat). Not only mankind but the entire homo lineage evolved during the current Ice Age (Mithen, 1996), which started about 2.5 million years ago. We simply have not evolved to cope with a hothouse Earth and might not be able to adapt to or even survive such a shift and its aftermath.

A non-linear shift into a different equilibrium affects all systems: sea level, winds, ocean currents, precipitation, temperature patterns, etc. There are two particularly worrying aspects of such a drastic and sudden transformation. First, we do not and cannot know how long it takes for the system the settle on regular weather patterns in the novel equilibrium. It might take "a blink of an eye" in geological terms, which, nevertheless could still mean thousands of years of erratic weather patterns, not suitable for agricultural production. Second, it's anthropogenic nature means that the shift itself is extremely rapid. There are sudden shifts in the fossil record, even dramatic warming events, for example the Paleocene-Eocene Thermal Maximum (PETM) (Murphy et al., 2010; Sluijs et al., 2011), when temperatures increased 56 million years ago, but they did so over a period of 150-200 kya, not 150-200 years. A few hundred thousand long blink of an eye could allow for animal and plant life to adapt, but even the PETM lead to a mass extinction, even in the tropics (Frieling et al., 2017). A 150-200 year transition might not leave time even for the most ancient species of our planet to prepare for and adopt to the hothouse state (as, for example, bird and insect populations, including pollinators, are already collapsing). Mass extinctions have not meant the collapse of entire ecosystems in the past. Now key ecosystems are driven towards a complete breakdown by human exploitation and pollution, over and above increasing temperatures. Sea level rise might be worrying for billions of people living in endangered coastal areas, but a sudden rise of waters combined with unpredictable 
weather patterns of a rapid, artificial transition to the hothouse state might not only lead to the collapse of the biosphere as we know it, mass extinction of most plant and animal life, but will preclude both large scale agriculture and animal farming as well.

The above scenario might be called "alarmist", but what is the adequate, reasonable risk probability that is acceptable scientifically, societally, politically, economically, and existentially, when it comes to the extinction of mankind? Current models suggest that we are going to reach a point of no return in 2030 (United Nations, 2019). However, there is no guarantee that it does not arrive sooner, which is especially worrying when considering that the process might be irreversible. The first tipping point, which is potentially the last one as well, might be passed even before the $1.5^{\circ} \mathrm{C}$ threshold set by the 2015 Paris Climate Agreement (which has been practically watered down to $2^{\circ} \mathrm{C}$ ). Such a possibility does not imply that it is already too late to take action, or climate doomism, but should motivate more and not less ambitious goals. Once Earth shifted into a hothouse state, it will make little sense to blame scientists for not having informed the public, but it might take humanity by surprise. Climate scientists certainly know about such potential scenarios but many might deem them too low probability or too complex to explain. However, their role in current circumstances is more akin to that of a medical doctor rather than of a curious investigator: prior to a life-saving operation we are not interested in the fine details of our medical condition but in the risks we take. Lethal side effects of climate destruction should be explicitly prioritized in communication, however unlikely they might be based on our current knowledge. Erring on the side of caution in the face of extinction might not be unreasonable. "Sciencing out" ourselves from a hothouse seems a pipedream, but sciencing ourselves out of a climactic collapse is more than feasible with the currently available technologies (Mann, 2021).

\subsection{Accurate metaphors, analogies and frames for the climate destruction}

How to talk about the climate so that the general public and even political and economic decision makers grasp the gravity of our current situation? We do not wish to tell what the right or wrong use of language is, or what the correct, appropriate, or preferred way to talk about the looming climactic apocalypse is. Novel practices should be developed and tested en mass by the scientific community, as the current dictionary seems to be inadequate to prompt action. We are going to suggest, however, some ideas for efficient and persuasive communication. The current terminology is well suitable for international political gatherings and briefings for business executives, but most of it misses the point in expressing the plain truth and geared to 
dodge responsibility. 'Diversity loss' is not a passive loss but an active overkill; 'carbon neutrality' has not much neutrality to it when it is used to cover up continuing emissions.

As a start, the cushy buzzwords and fluffy metaphors surrounding the anthropogenic climate destruction should be revised. Instead of 'greenhouse' science communicators could use 'hothouse'. The blanket metaphor could be entirely dropped because the accompanying explanation should be that the atmosphere is not like a removable blanket. There has been a trend in progressive journals to drop the term 'climate change' and use instead 'climate breakdown' or 'climate catastrophe'. However, these terms are passive and imply a non-human induced, natural process, against which mankind is helpless, and for which mankind is not responsible (responsibility is not equally spread of course but certainly shared). For example, 'climate destruction' is an active and descriptive term. Instead of 'global warming' the term 'global overheating' might be more straight to the point. In addition, whenever a novel term is introduced, caution should be taken so that its meaning is not easy diluted by corporate interests as it has been done with 'carbon footprint', for example.

Secondly, when conceiving novel metaphors or when turning analogies into metaphors, scientists should carefully consider the possible literal interpretations, and specifically whether they can be distorted to contradict their main message or confuse the audience. Emotional valence is also a critical issue: dire messages cannot be transmitted by positive or neutral terms. Metaphors should be of course detailed and explained, but they should be created in a way that allows them to convey their gist with no necessary additional context. The spread of figurative terms is not entirely explained neither by memetics nor epidemiology: it is typically the form that is spreading, not the content, be their hypothetical relationship firm (memetic) or loose (epidemiology). In the conceptualization of memetics, memes are spreading, but malignant ones are often 'memetically engineered' and artificially disseminated. The intended meaning of epidemically spreading messages can also easily be lost or strategically misrepresented: cultural attractors can be targets of corporate PR manipulations. The intricacy of accurate figurative buzzwords is that they should be able to transduce the figurative, abstract meaning they refer to (i.e. the climate threat) to an extent that even a literal reading does not under cut the message as a whole (by a misleading image, pleasantness, or neutrality).

A third potential twist in communication is that it should not emit helpless doomism, because all the necessary technologies to avert the collapse of our biosphere, by eliminating emissions are restoring natural renewal, are available - the primary question is that of willingness. Moreover, it should not have to preach a puritan, purist lifestyle either (Mann, 2021). CFCs were banned, why should the use of plastics and pollutants be a personal decision? 
The ozone hole was not healed by abandoning refrigerators as part of a new, self-restrictive lifestyle but by regulation and novel technology. The problem is not with plastic itself, but the kind of plastic derived from oil, which is not biodegradable and not recyclable (and there are such alternatives). Likewise, the problem is not cars, airplanes or energy production, but the current technologies utilized for engines and power plants, etc. We are at a technological bottleneck that drove our planet to the brink of collapse, but clean energy and green technology are available and able to provide a technological solution for sustainable, high-tech and quality life. Importantly, it is the wealthiest segments of the world that are responsible for the vast majority of emissions and pollution, and this is why even the global COVID lockdown (spring 2020) did not bring a reduction in carbon emission greater than $15-20 \%$. It might worth considering for climate scientists and communicators to target primarily the political-economic leadership (including supply chain CEOs, local politicians, etc.), as public awareness, protests, or life-style change neither have had an impact, nor are sufficient.

By ringing the alarm bells with limited collective demonstrative action, patiently convening on conferences, diligently negotiating and infinitesimally explaining climate science to political and economic decision makers for decades to no avail, the scientific community might appear a bit confusing for the general public - and perhaps even for the economicpolitical establishment itself. Why the warnings, if things are allowed to go on? Why the alarmism if nothing serious has happened so far? Climate scientists and those in possession of the knowledge about the current dire state of planet Earth's climate and biosphere bear the most responsibility in the times of suicidal anthropogenic climate destruction to warn mankind, in word and if need be in deeds. True communicative intentions are often inferred based on actions not on intricate argumentation and reasoning based on complex data.

\section{An epistemological stance in scientific communication}

Large swaths of the general public, including well educated people are often irritated by the apparent contradictions in science news: "last year eggs were discovered to be harmful, then that they are not, now they are harmful again." The sensationalist media culture and the lure of fame for researchers both contribute to the circulation of bombastic scientific statements which are later refuted in similarly theatrical manner. The scientific process becoming faster, more transparent and accessible have exacerbated the problem by providing insight into previously hidden internal debates. The ambiguity, the contradictions, the falsification and revisions of theories are all mundane daily experience of researcher, but apparently rather frustrating for the 
rest - even though skepticism evaporates rapidly when forensic or medical science is desired. Here we present a few ideas from cognitive science for science communicators, researchers, educators, policy makers and journalists alike on effective means of transmitting research findings.

\subsection{The cognitive capacities underlying folk epistemology}

There was important turn in cognitive science in the 1980s when non-scientific, naïve or folk theories of the world of everyday people gained interest. These theories are naïve in the sense that they are incomplete and are based on experience rather than science, but they are not necessarily wrong; they form a common sense world knowledge. Naïve physics is how most people think about the physical world, not physicists (Hayes, 1979). Likewise, naïve biology (Hatano \& Inagaki, 1994; Medin \& Atran, 2004) naïve geography (Egenhofer \& Mark, 1995) or naïve psychology (Clark, 1987) can tell a lot about how we conceive our environment but also about the cognitive mechanisms by which we do so. A parallel has been drawn between the investigations of scientists and infants when exploring and understanding the world (Gopnik \& Meltzoff, 1998). Even though there does not seem to be a naïve climate theory, there is a long history of folk wisdom that predicts likely weather patterns based on observations (which is being rendered obsolete by climate destruction). Understanding the capacities and limits of our naïve sciences, basic innate systems and folk beliefs are crucial for creating public messages that work.

One example of our cognitive limits is the notion of causality (Michotte, 1963): causation is understood in infancy both in the physical (collisions) and in the social domain (goals) already before infants are able to reach (Liu et al., 2019). However, understanding mental causation, that is, conceiving and explaining the behavior of others as driven by intentions, beliefs and desires, an ability often called mentalization, is a piecemeal process. Infants attribute beliefs already around 6-7 months of age (Kovács et al., 2010; Southgate \& Vernetti, 2014), and infants' attributions are not merely about perceptions but real mental representations (Forgács et al., 2020). However, children experience problems predicting or explaining behavior and thoughts of others when explicitly asked about true or false beliefs, up to 10 years of age (Oktay-Gür \& Rakoczy, 2017). It is one thing to generate ideas that could be attributed to others, but it is another thing to explain behavior correctly. Yet we attribute mental causes exuberantly even to pets, computers, to geometrical shapes (Heider \& Simmel, 1944) including nature herself. In sum, we spontaneously and innately attribute invisible forces of causation and we attribute intentions excessively even to entities not having any, which are 
perhaps driving the ancient animistic attitude towards nature. Thinking about natural phenomenon in terms of intentions ("it won't stop raining") or even of agents ("winter is coming") makes it easy to attribute climate destruction to mystical beings of nature, which also levies us from taking responsibility for the carnage. Leaving a habitable planet to all future generations starts with growing up and taking responsibility instead of filling our world with invisible agents, on the one hand. Talking about climate challenges might be more comprehendible if it revolved around actual intentions of actual actors, on the other.

\subsection{Failures of naïve statistics}

Another considerable cognitive burden of comprehending and communicating scientific facts is that there are serious limitations to the comprehension of probabilities, predictions, and risks that fall outside of typical human cognitive capacities. Non-linear processes, exponential growth, sudden transformations, and probabilities outside of everyday statistical reasoning are notoriously difficult to conceive (Gigerenzer, 1991). For example, it is not clear for many people that an $85 \%$ probability of protection from a virus is a $15 \%$ certainty of infection: out of 100 people 15 will definitely contract it. In other words, probability might be easier to grasp when framed not as avoidable chance but as rare certainty. It might also be difficult to imagine that a quantitative, gradual change could lead to an irreversible qualitative change. One example highlighting the issues is the "pin theory": if each passenger of an plane pulls out a pin, the plane is going to fly for quite some time before falling apart.

It is also challenging to consider rare events (e.g., extreme storms) to be part of an overarching pattern or that they more probable than they seem. When driving a car, we might settle with considerable risks as most of them are non-lethal, however, we have rather different preferences for flying with a lot fewer, less probable but definitely lethal risks. The systemic overweighting of low probabilities and underweighting events with high probabilities was part of a work that earned a Nobel prize (Kahneman \& Tversky, 1979). Threats posed by climate destruction might be incomprehensible for laypeople, unless dangers are communicated not as present hypotheticals, but future certainties.

\subsection{The limits of human reasoning}

Initially it took psychologist by surprise that most people do not perform well in rather simple logical reasoning tasks (Wason, 1966). Decades of ensuing research showed that most reasoning is not based on logic, but on heuristics and systematic distortions, or biases (Tversky \& Kahneman, 1974). However, not even knowing about these biases leads to better reasoning, 
just more sophisticated compensatory mechanisms, which lead to the dual process theory of reasoning (Kahneman, 2011). Supposedly, we typically make rapid but biased, rigid, intuitive, heuristics-based decisions unless we make considerable effort and use a more flexible but slow system of reasoning. The theory implies that we could be correct in our judgement, if only we strived to.

Other cognitive scientists are on a different opinion, however, and suggest that there is no such process as intuition: we just do not know how we have come to some conclusions. The argumentative theory of reasoning (Mercier \& Sperber, 2017) proposes that reasoning is providing arguments for others and ourselves for choosing a particular course of action - and there is nothing biased in such self-justification. There are no two systems for making decision, and reasoning is not for reaching conclusions, but to justify them. This system can be exploited and developed to provide strong reasons outside of the social domain, but mostly we are guessing when we are pressed to explain ourselves after having made decisions, and we make decisions based on arguments we deem defensible - not on pure reason.

In other words, everyday reasoning has not got much to do with logic and the fine mental operations developed by philosophers or economist. It is perhaps not surprising that general education does not improve either everyday decision making or reasoning; education does not improve social, societal or political decisions either, as these mostly express social affiliation and belonging, rather than reason. In a highly politicized environment, the fight against climate destruction might sound for sceptics as an irksome tribal call instead of a voice of reason. It is possible that at least as long as the nature of the climate threat is not clear, emotional messages might serve survival better than lengthy arguments based on statistics. It is also factually true that from now on each next generation is going to suffer more than any previous one.

\subsection{New foundations for a bolder science communication culture}

How can science communicators improve the effectiveness of their messages? Sperber and Wilson's (1986) Relevance Theory suggests that we gain a greater cognitive effect for the very same bit of information - inter alia - if we need to make less effort for it. Thus, messages should be simple. However, it also suggests that we expect an optimal level of relevance struck by the speaker. Therefore, if we do not get the message first (we cannot reach an effect easily), assuming that the speaker adjusted the massage to our cognitive abilities and willingness to pay attention, we go on making more and more effort to dig up the effect (message) meant for us. This process can run away with intellectual tsars, called the guru-effect by Sperber (2010): we keep putting in ever more effort in trying to understand texts that do not necessarily have a lot 
to say, but are complicated enough to make the impression of an expert opinion. Because of the excessive effort, eventually an unwarranted amount of effect is derived: the message must be incredibly sophisticated and elaborate, because, and mostly because, the guru has said so. If this process describes the state of affairs correctly, simple messages can be wrapped up in a bit more complicated forms, which require some more effort, but yield some extra effects as well. They should be not too complicated, so hearers do not give up processing easily, but not too simple either, so that the audience stop by to think and get immersed a bit deeper.

Serious scientists can easily make the error of communicating in a complicated manner, without making an effort to simplify their message sufficiently, thereby risking to lose the attention of their audience. Science journalists easily fall prey of making the message so simple and bombastic that not only truth is not fully preserved, but attention is grabbed for such a short instant and effort is so minimal, that it does not yield cognitive effects memorable beyond the moment. It is the common responsibility of all science communicators to figure out the optimal effect-effort balance when communicating the dire consequences of $0.5^{\circ} \mathrm{C}$ additional global warming, for example. Relevance Theory also suggests that meaning is inferred not only from what is said, but also based on the cognitive environment, which includes background knowledge, common history, culture, communicational common ground, etc. The same sentence sounds very differently on the third week of a global strike of climate scientist on a demonstration they organized, than calmly explained behind closed doors in an airconditioned room in Davos.

Whether scientific theories capture the imagination of people and spread successfully because of the vivid images their metaphors evoke or the literal accurateness of their foundations is not possible to tell in advance. Einstein's relativity theory passed both tests: visionary analogies, metaphors, and thought experiments were backed up with sound calculations. Such great metaphors take a lot of effort to develop, but a global community of climate scientists, in unanimous agreement regarding the dire consequences of the anthropogenic climate and biosphere destruction, has an enormous intellectual potential if once it dares to stand up to boldly speak out. Ecosystems are not possible to restore from gene banks, which is a nice but naïve idea: with no biological context, that is, functioning ecosystem individual species cannot be saved. Climate and biosphere destruction goes hand in hand, but mankind is not likely to survive either. Whether a war metaphor is useful in the context of climate change, is an empirical question. However, it seems to be the case that after decades of delsay only a war-time-like effort will have the power to stabilize the biosphere. The good news is that, although the days are numbered, an all-out effort can still save Earth and humanity. 


\section{References}

Aristotle 350 BC. (1968). Poetics (D. W. Lucas (Ed.)). Oxford University Press.

Armstrong, A. K., Krasny, M. E., \& Schuldt, J. P. (2019). Using metaphor and analogy in climate change communication. In Communicating Climate Change (pp. 70-74). Cornell University Press. https://doi.org/10.7591/9781501730801-013

Bill, G. (2021). How to Avoid a Climate Disaster: The Solutions We Have and the Breakthroughs We Need. Allen Lane.

Binder, J. R., \& Desai, R. H. (2011). The neurobiology of semantic memory. Trends in Cognitive Sciences, 15(11), 527-536. https://doi.org/10.1016/j.tics.2011.10.001

Blasko, D. G., \& Connine, C. M. (1993). Effects of familiarity and aptness on metaphor processing. Journal of Experimental Psychology: Learning, Memory, and Cognition, 19(2), 295-308. https://doi.org/10.1037//0278-7393.19.2.295

Bohrn, I. C., Altmann, U., \& Jacobs, A. M. (2012). Looking at the brains behind figurative language-A quantitative meta-analysis of neuroimaging studies on metaphor, idiom, and irony processing. Neuropsychologia, 50(11), 2669-2683. https://doi.org/10.1016/j.neuropsychologia.2012.07.021

Bowdle, B. F., \& Gentner, D. (2005). The career of metaphor. Psychological Review, 112(1), 193-216. https://doi.org/10.1037/0033-295X.112.1.193

Bréal, M. (1900). Semantics: Studies in the Science of Meaning. Henry Holt \& Co.

Broadbent, D. E. (1958). Perception and Communication. Pergamon Press. https://books.google.co.uk/books?id=GwtKAAAAMAAJ

Brysse, K., Oreskes, N., O’Reilly, J., \& Oppenheimer, M. (2013). Climate change prediction: Erring on the side of least drama? Global Environmental Change, 23(1), 327-337. https://doi.org/10.1016/j.gloenvcha.2012.10.008

Burkeman, O. (2003). Memo exposes Bush's new green strategy | Environment. The Guardian. https://www.theguardian.com/environment/2003/mar/04/usnews.climatechange

Cameron, L. J. (2007). Patterns of metaphor use in reconciliation talk. Discourse and Society, 18(2), 197-222. https://doi.org/10.1177/0957926507073376

Ceballos, G., Ehrlich, P. R., \& Raven, P. H. (2020). Vertebrates on the brink as indicators of biological annihilation and the sixth mass extinction. Proceedings of the National Academy of Sciences of the United States of America, 117(24), 13596-13602. https://doi.org/10.1073/pnas.1922686117

Chen, X. (2012). The Greenhouse Metaphor and the Greenhouse Effect: A Case Study of a Flawed Analogous Model. In Research Topics in Wind Energy (Vol. 2, pp. 105-114). 
https://doi.org/10.1007/978-3-642-29928-5_5

Citron, F. M. M., \& Goldberg, A. E. (2014). Metaphorical Sentences Are More Emotionally Engaging than Their Literal Counterparts. Journal of Cognitive Neuroscience, 26(11), 2585-2595. https://doi.org/10.1162/jocn_a_00654

Clark, A. (1987). From folk psychology to naive psychology. Cognitive Science. https://doi.org/10.1016/S0364-0213(87)80002-2

Cooper, G. S., Willcock, S., \& Dearing, J. A. (2020). Regime shifts occur disproportionately faster in larger ecosystems. Nature Communications, 11(1). https://doi.org/10.1038/s41467-020-15029-X

Csibra, G., \& Gergely, G. (2009). Natural pedagogy. Trends in Cognitive Sciences, 13(4), 148153. https://doi.org/10.1016/j.tics.2009.01.005

Csibra, G., \& Gergely, G. (2011). Natural pedagogy as evolutionary adaptation. Philosophical Transactions of the Royal Society B: Biological Sciences, 366(1567), 1149-1157. https://doi.org/10.1098/rstb.2010.0319

Dawkins, R. (1976). The selfish gene. New York. In Oxford Univ. Press.

De Bolle, M. (2019). Policy Brief 19-15: The Amazon Is a Carbon Bomb: How Can Brazil and the World Work Together to Avoid Setting It Off? Peterson Institute for International Economics, 1-8. https://www.piie.com/publications/policy-briefs/amazon-carbon-bombhow-can-brazil-and-world-work-together-avoid-setting\%0Awww.piie.com

Deignan, A., Semino, E., \& Paul, S.-A. (2019). Metaphors of climate science in three genres: Research articles, educational texts, and secondary school student talk. Applied Linguistics, 40(2), 379-403. https://doi.org/10.1093/applin/amx035

Du Marsais, C. C. (1740). Des Tropes. Ou Des différents sens dans lesquels on peut prendre un même mot dans une même langue. Le Philologue, Editions Manucius.

Egenhofer, M. J., \& Mark, D. M. (1995). Naive geography. Lecture Notes in Computer Science (Including Subseries Lecture Notes in Artificial Intelligence and Lecture Notes in Bioinformatics), 988, 1-15. https://doi.org/10.1007/3-540-60392-1_1

Eysenck, H. J. (2000). Smoking, health and personality. Transaction Publishers.

Farrell, J. (2016). Corporate funding and ideological polarization about climate change. Proceedings of the National Academy of Sciences of the United States of America. https://doi.org/10.1073/pnas.1509433112

Fisher, R. A. (1958). Cancer and smoking. Nature. https://doi.org/10.1038/182596a0

Fónagy, I. (1963). Érzelmek kifejező mozgása a gége szintjén. Magyar Pszichológiai Szemle, 20, 206-216. 
Fónagy, I. (2001). Languages within Language. Benjamins.

Forgács, B. (2020). An Electrophysiological Abstractness Effect for Metaphorical Meaning Making. Eneuro, 7(5), ENEURO.0052-20.2020. https://doi.org/10.1523/ENEURO.005220.2020

Forgács, B. (2021). The pragmatic functions of metaphorical language. In G. Csibra, J. Gervain, \& K. Kovács (Eds.), The Diversity of the Mind - Cognitive Science in and Around Central Europe (pp. 1-20). Springer.

Forgács, B., Bardolph, M. D., Amsel, B. D., DeLong, K. A., \& Kutas, M. (2015). Metaphors are physical and abstract: ERPs to metaphorically modified nouns resemble ERPs to abstract language. Frontiers in Human Neuroscience, 9, 28. https://doi.org/10.3389/fnhum.2015.00028

Forgács, B., Bohrn, I., Baudewig, J., Hofmann, M. J., Pléh, C., \& Jacobs, A. M. (2012). Neural correlates of combinatorial semantic processing of literal and figurative noun noun $\begin{array}{llll}\text { compound } \quad \text { words. } & \text { NeuroImage, } & \text { 63(3), }\end{array}$ https://doi.org/10.1016/j.neuroimage.2012.07.029

Forgács, B., Gervain, J., Parise, E., Csibra, G., Gergely, G., Baross, J., \& Király, I. (2020). Electrophysiological investigation of infants' understanding of understanding. Developmental Cognitive Neuroscience, 100783. https://doi.org/10.1016/j.den.2020.100783

Forgács, B., Lukács, Á., \& Pléh, C. (2014). Lateralized processing of novel metaphors: Disentangling figurativeness and novelty. Neuropsychologia, 56(1). https://doi.org/10.1016/j.neuropsychologia.2014.01.003

Forgács, B., \& Pléh, C. (2019). What are you thinking about where? Syntactic ambiguity between abstract arguments and concrete adjuncts in Hungarian, modulated by concreteness. Psychology in Russia: State of the Art, 12(1), 67-78. https://doi.org/10.11621/pir.2019.0105

Franta, B. (2018). Shell and Exxon's secret 1980s climate change warnings. The Guardian. https://www.theguardian.com/environment/climate-consensus-97-percent/2018/sep/19/shell-and-exxons-secret-1980s-climate-change-warnings

Frieling, J., Gebhardt, H., Huber, M., Adekeye, O. A., Akande, S. O., Reichart, G. J., Middelburg, J. J., Schouten, S., \& Sluijs, A. (2017). Extreme warmth and heat-stressed plankton in the tropics during the Paleocene-Eocene Thermal Maximum. Science Advances, 3(3). https://doi.org/10.1126/sciadv.1600891

Gallese, V., \& Lakoff, G. (2005). The Brain's Concepts: The Role of the Sensory-Motor System 
in Conceptual Knowledge. Cognitive Neuropsychology, 22(3-4), 455-479. https://doi.org/10.1080/02643290442000310

Gergely, G., Bekkering, H., \& Király, I. (2002). Rational imitation in preverbal infants. Nature, 415(6873), 755. https://doi.org/10.1038/415755a

Gigerenzer, G. (1991). How to Make Cognitive Illusions Disappear: Beyond "Heuristics and Biases.” In W. Stroebe \& M. Hewstone (Eds.), European Review of Social Psychology (Vol. 2, pp. 83-115). John Wiley \& Sons. https://doi.org/10.1080/14792779143000033

Gigerenzer, G., \& Murray, D. J. (1987). Cognition as Intuitive Statistics. In Cognition as Intuitive Statistics. Psychology Press.

Gleick, J. (2011). Chaos: Making a New Science. Open Road Media. https://books.google.hu/books?id=OoLNzl4XpPUC

Glucksberg, S. (2003). The psycholinguistics of metaphor. Trends in Cognitive Sciences, 7(2), 92-96. https://doi.org/10.1016/S1364-6613(02)00040-2

Gopnik, A., \& Meltzoff, A. N. (1998). Words, Thoughts, and Theories. In Words, Thoughts, and Theories. The MIT Press. https://doi.org/10.7551/mitpress/7289.001.0001

Grice, H. P. (1975). Logic and conversation. In P. Cole \& J. Morgan (Eds.), Syntax and semantics 3 : Speech arts (pp. 41-58).

Hall, S. (2015). Exxon Knew about Climate Change Almost 40 Years Ago - Scientific American. Scientific American. https://www.scientificamerican.com/article/exxon-knewabout-climate-change-almost-40-years-ago/

Hatano, G., \& Inagaki, K. (1994). Young children's naive theory of biology. Cognition. https://doi.org/10.1016/0010-0277(94)90027-2

Hayes, P. J. (1979). The Naive Physics Manifesto. In D. Michie (Ed.), Expert Systems in the Micro-Electronic Age. Edinburgh University Press.

Heider, F., \& Simmel, M. (1944). An Experimental Study of Apparent Behavior. The American Journal of Psychology. https://doi.org/10.2307/1416950

Horner, V., \& Whiten, A. (2005). Causal knowledge and imitation/emulation switching in chimpanzees (Pan troglodytes) and children (Homo sapiens). Animal Cognition, 8(3), 164-181. https://doi.org/10.1007/s10071-004-0239-6

Hulac, B. (2016). Tobacco and Oil Industries Used Same Researchers to Sway Public. Scientific American. https://www.scientificamerican.com/article/tobacco-and-oil-industries-usedsame-researchers-to-sway-public1/

Jakobson, R. (1960). Linguistics and poetics. In Style in language (pp. 350-377). MIT Press.

Kahneman, D. (2011). Thinking fast and thinking slow. Macmillan. 
Kahneman, D., \& Tversky, A. (1979). Prospect Theory: An Analysis of Decision under Risk. Econometrica, $47(2)$,

263-292.

http://www.jstor.org/stable/1914185\%5Cnhttp://www.jstor.org/\%5Cnhttp://www.jstor.or g/action/showPublisher?publisherCode=econosoc.\%5Cnhttp://www.jstor.org

Kovács, Á. M., Teglás, E., \& Endress, A. D. (2010). The Social Sense: Susceptibility to Others’ Beliefs in Human Infants and Adults. Science, 330(6012), 1830-1834. https://doi.org/10.1126/science.1190792

Kuusinen, J. (1969). Affective and denotative structures of personality ratings. Journal of Personality and Social Psychology. https://doi.org/10.1037/h0027713

Lacey, S., Stilla, R., \& Sathian, K. (2012). Metaphorically feeling: Comprehending textural metaphors activates somatosensory cortex. Brain and Language, 120(3), 416-421. https://doi.org/10.1016/j.bandl.2011.12.016

Lakoff, G., \& Johnson, M. (1980). Methapors We Live By. University of Chicago Press.

Lakoff, G., \& Johnson, M. (1999). Philosophy in the Flesh: The Embodied Mind and its Challenge to Western Thought. Basic Books.

Leary, D. E. (1990). Psyche's muse: The role of metaphor in the history of psychology. In Metaphors in the history of psychology.

Levine, K. J., Clark, N., Haygood, D. M., \& Muenchen, R. A. (2011). Change: How young voters interpreted the messages sent during the 2008 presidential election season. American Behavioral Scientist. https://doi.org/10.1177/0002764211398075

Liu, S., Brooks, N. B., \& Spelke, E. S. (2019). Origins of the concepts cause, cost, and goal in prereaching infants. Proceedings of the National Academy of Sciences of the United States of America, 116(36), 17747-17752. https://doi.org/10.1073/pnas.1904410116

Mann, M. E. (2021). The New Climate War: The Fight to Take Back Our Planet. PublicAffairs.

Medin, D. L., \& Atran, S. (2004). The Native Mind: Biological Categorization and Reasoning in Development and Across Cultures. Psychological Review, 111(4), 960-983. https://doi.org/10.1037/0033-295X.111.4.960

Mercier, H., \& Sperber, D. (2017). The Enigma of Reason. In The Enigma of Reason. Harvard University Press. https://doi.org/10.4159/9780674977860

Michotte, A. (1963). The Perception of Causality. In The Perception of Causality. Routledge. https://doi.org/10.4324/9781315519050

Mithen, S. (1996). The Prehistory of The Mind. Thames and Hudson.

Murphy, B. H., Farley, K. A., \& Zachos, J. C. (2010). An extraterrestrial 3He-based timescale for the Paleocene-Eocene thermal maximum (PETM) from Walvis Ridge, IODP Site 
1266. Geochimica et Cosmochimica Acta, 74(17), 5098-5108. https://doi.org/10.1016/j.gca.2010.03.039

Murphy, G. L. (1997). Reasons to doubt the present evidence for metaphoric representation.

Cognition, 62, 99-108. https://doi.org/10.1016/S0010-0277(96)00725-1

Oktay-Gür, N., \& Rakoczy, H. (2017). Children's difficulty with true belief tasks: Competence deficit or performance problem? Cognition, 166, 28-41. https://doi.org/10.1016/j.cognition.2017.05.002

Ortiz, M., \& Jordán, F. (2021). Modelling and Conservation of Coastal Marine Ecosystems in Latin America. In M. Ortiz \& F. Jordán (Eds.), Marine Coastal Ecosystems Modelling and Conservation (pp. 203-207). Springer. https://doi.org/10.1007/978-3-030-58211-1_10

Ortony, A., Schallert, D. L., Reynolds, R. E., \& Antos, S. J. (1978). Interpreting Metaphors and Idioms: Some Effects of Context on Comprehension. Journal of Verbal Learning and Verbal Behavior, 17, 465-477. https://doi.org/http://dx.doi.org/10.1016/S00225371(78)90283-9

Osgood, C. E. (1962). Studies on the generality of affective meaning systems. American Psychologist. https://doi.org/10.1037/h0045146

Pinker, S. (2010). The cognitive niche: Coevolution of intelligence, sociality, and language. Proceedings of the National Academy of Sciences of the United States of America, 107(Supplement 2), 8993-8999. https://doi.org/10.1073/pnas.0914630107

Pinker, S., Nowak, M. A., \& Lee, J. J. (2008). The logic of indirect speech. Proceedings of the National Academy of Sciences of the United States of America, 105(3), 833-838. https://doi.org/10.1073/pnas.0707192105

Pléh, C. (2000). Modularity and pragmatics. Pragmatics. Quarterly Publication of the International Pragmatics Association (IPrA), 10(4), 415-438. https://doi.org/10.1075/prag.10.4.04ple

Pléh, C. (2003). Thoughts on the Distribution of Thoughts: Memes or Epidemies. Journal of Cultural and Evolutionary Psychology, 1(1), 21-51. https://doi.org/10.1556/jcep.1.2003.1.3

Pomp, J., Bestgen, A. K., Schulze, P., Müller, C. J., Citron, F. M. M., Suchan, B., \& Kuchinke, L. (2018). Lexical olfaction recruits olfactory orbitofrontal cortex in metaphorical and literal contexts. Brain and Language, 179, 11-21. https://doi.org/10.1016/j.bandl.2018.02.001

Pulvermüller, F. (2005). Brain mechanisms linking language and action. Nature Reviews Neuroscience, 6(7), 576-582. https://doi.org/10.1038/nrn1706 
Rapp, A. M., Mutschler, D. E., \& Erb, M. (2012). Where in the brain is nonliteral language? A coordinate-based meta-analysis of functional magnetic resonance imaging studies. NeuroImage, 63(1), 600-610. https://doi.org/10.1016/j.neuroimage.2012.06.022

Rocha, J. C., Peterson, G., Bodin, Ö., \& Levin, S. (2018). Cascading regime shifts within and across scales. Science, 362(6421), 1379-1383. https://doi.org/10.1126/science.aat7850

Russill, C. (2011). Temporal Metaphor in Abrupt Climate Change Communication: An Initial Effort at Clarification. In W. Leal Filho (Ed.), The Economic, Social and Political Elements of Climate Change (pp. 113-132). Springer Berlin Heidelberg. https://doi.org/10.1007/978-3-642-14776-0

Shannon, C. E. (1948). A Mathematical Theory of Communication. The Bell System Technical Journal, 27(3), 379-423.

Sluijs, A., Bijl, P. K., Schouten, S., Röhl, U., Reichart, G. J., \& Brinkhuis, H. (2011). Southern ocean warming, sea level and hydrological change during the Paleocene-Eocene thermal maximum. Climate of the Past, 7(1), 47-61. https://doi.org/10.5194/cp-7-47-2011

Southgate, V., \& Vernetti, A. (2014). Belief-based action prediction in preverbal infants. Cognition, 130(1), 1-10. https://doi.org/10.1016/j.cognition.2013.08.008

Sperber, D. (1985). Anthropology and Psychology: Towards an Epidemiology of Representations. Man, 20(1), 73. https://doi.org/10.2307/2802222

Sperber, D. (1996). Explaining Culture: A Naturalistic Approach. Blackwell Publishers.

Sperber, D. (2001). An objection to the memetic approach to culture. In R. Aunger (Ed.), Darwinizing Culture: The Status of Memetics as a Science (pp. 163-173). Oxford University Press. https://doi.org/10.1093/acprof:oso/9780192632449.003.0008

Sperber, D. (2010). The Guru Effect. Review of Philosophy and Psychology, 1(4), 583-592. https://doi.org/10.1007/s13164-010-0025-0

Sperber, D., \& Wilson, D. (1986). Relevance: Communication and Cognition. Blackwell.

Sperber, D., \& Wilson, D. (1998). The mapping between the mental and the public lexicon. In P. Carruthers \& J. Boucher (Eds.), Thought and language (pp. 184-200). Cambridge University Press.

Sperber, D., \& Wilson, D. (2008). A deflationary account of metaphors. In R. Gibbs (Ed.), The Cambridge Handbook of Metaphor and Thought (pp. 84-105). Cambridge University Press.

Steffen, W., Rockström, J., Richardson, K., Lenton, T. M., Folke, C., Liverman, D., Summerhayes, C. P., Barnosky, A. D., Cornell, S. E., Crucifix, M., Donges, J. F., Fetzer, I., Lade, S. J., Scheffer, M., Winkelmann, R., \& Schellnhuber, H. J. (2018). Trajectories 
of the Earth System in the Anthropocene. Proceedings of the National Academy of Sciences of the United States of America, 115(33), 8252-8259. https://doi.org/10.1073/pnas.1810141115

Supran, G., \& Oreskes, N. (2020). Addendum to 'Assessing ExxonMobil's climate change communications (1977-2014)' Supran and Oreskes (2017 Environ. Res. Lett. 12 084019). Environmental Research Letters, 15(11), 119401. https://doi.org/10.1088/17489326/ab89d5

Thibodeau, P. H., \& Boroditsky, L. (2015). Measuring effects of metaphor in a dynamic opinion landscape. PLoS ONE, 10(7), 1-22. https://doi.org/10.1371/journal.pone.0133939

Tversky, A., \& Kahneman, D. (1974). Judgment under Uncertainty: Heuristics and Biases. Science, 185(4157), 1124-1131.

United Nations. (2019). Only 11 years left to prevent irreversible damage from climate change, speakers warn during General Assembly High-Level Meeting. United Nations General Assembly. https://www.un.org/press/en/2019/ga12131.doc.htm

Van Lancker Sidtis, D. (2006). Does functional neuroimaging solve the questions of neurolinguistics? Brain and Language, 98(3), 276-290. https://doi.org/10.1016/j.bandl.2006.05.006

Volmert, A. (2014). Getting to the heart of the matter: Using Metaphorical and Causal Explanation to Increase Public Understanding of Climate and Ocean Change. Assessing Children in the Urban Community, May, 159-164. https://www.frameworksinstitute.org/wpcontent/uploads/2020/03/occ_metaphor_report.pdf

Wason, P. C. (1966). Reasoning. In B. Foss (Ed.), New Horizons in Psychology. Penguin.

Wilson, D., \& Sperber, D. (2002). Truthfulness and relevance. Mind, 111(July), 583-632. https://doi.org/10.1093/mind/111.443.583

Winner, E., \& Gardner, H. (1977). The comprehension of metaphor in brain-damaged patients. Brain, 100(4), 717-729. https://doi.org/10.1093/brain/100.4.717

Yang, J. (2014). The role of the right hemisphere in metaphor comprehension: A meta-analysis of functional magnetic resonance imaging studies. Human Brain Mapping, 35(1), 107122. https://doi.org/10.1002/hbm.22160

Yvon-Durocher, G., Allen, A. P., Bastviken, D., Conrad, R., Gudasz, C., St-Pierre, A., ThanhDuc, N., \& Del Giorgio, P. A. (2014). Methane fluxes show consistent temperature dependence across microbial to ecosystem scales. Nature, 507(7493), 488-491. https://doi.org/10.1038/nature13164 
